\title{
REDESCOBRINDO O CENTRO DE MEMÓRIA DA ESCOLA DE ENFERMAGEM DE RIBEIRÃO PRETO: RELATO DE EXPERIÊNCIA
}

Rediscovering the Memory Center at the

Ribeirão Preto College of Nursing: An experience report

Redescubriendo el Centro de Memoria de la

Escuela de Enfermería de Ribeirão Preto: Un relato de experiencia

Luciana Barizon Luchesi

Margarita Antonia Villar Luis
Isabel Amélia Costa Mendes

Toyoko Saeki

\section{Resumo}

Por meio de relato de experiência, apresenta-se a atuação de um grupo de docentes e alunos no processo de reorganização do Centro de Memória da Escola de Enfermagem de Ribeirão Preto da Universidade de São Paulo no triênio 2002-2005. Após o resgate da criação do referido Centro, aborda-se sobre os procedimentos e atividades desenvolvidos na reorganização do Centro, em termos de coleção fotográfica, capacitação do grupo, promoção de eventos e inserção de atividades práticas para estimular o interesse dos alunos pela História da Enfermagem.

Palavras-chave: Enfermagem. História da enfermagem. Memória. Arquivos. Educação em Enfermagem.

\begin{abstract}
Through an experience report is presented the performance of a group of professors and students in the process of reorganization of the Memory Center of the Ribeirão Preto College of Nursing from University of São Paulo in the period of 2002-2005. After the rescue of creation of the related Center, it is approached the procedures and activities developed in the reorganization of the Center, in terms of photographic collection, group qualification, promotion of events and insertion of practical activities to stimulate the students interest for the History of nursing.
\end{abstract}

\section{Resumen}

Por medio de la narración de experiencias se presentan las actividades de un grupo de docentes y alumnos en proceso de reorganización del Centro de Memoria de la Escuela de Enfermería de Ribeirão Preto de la Universidad de "São Paulo" en el trienio 2002-2005. Posterior a la recuperación de la creación del Centro, se trató sobre los procedimientos y actividades desarrolladas en su reorganización, en términos de colección fotográfica, capacitación grupal, promoción de eventos e introducción de actividades prácticas para estimular el interés de los estudiantes por la historia de enfermería.
Keywords: Nursing. History of Nursing. Memory. Archives. Education, Nursing.
Palabras clave: Enfermería. Historia de la Enfermería. Memoria. Archivos. Educación en Enfermería. 